\title{
DEVELOPMENT OF THE POTATO TUBER CUTTING PROTOTYPE
}

\author{
Elghobashy, H** ; I. Yehia**; Y.A. Shaaban*
}

\begin{abstract}
A locally made potato seed cutting prototype was designed, manufactured and evaluated. According to the physical and mechanical properties that related for cutting the prototype was designed. The prototype consists of three essential parts, included potato cutting system, power transmission and feeding systems. The prototype performance was evaluated at the variables of two potato varieties (Sponta \& Diamond), three mass categories $C_{m 1}(90-150 g), C_{m 2}(150-210 \mathrm{~g}) \& C_{m 3}(210-300 \mathrm{~g})$ and three plunger speeds $(0.08,0.12$ and $0.16 \mathrm{~m} / \mathrm{s})$. The evaluation parameters are the prototype productivity, cutting uniformity, cutting losses, mechanical injury and specific energy consumption. The proper uniformity of the cutting prototype of 76.8, 78.4 and 81.3 for Sponta and 68.2, 78.4 and 81.3 for Diamond were obtained at $0.08 \mathrm{~m} / \mathrm{s}$ of the plunger speed for the three tubers mass categories, respectively. The mean value of the prototype productivity of $0.18 \mathrm{Mgh}^{-1}$ was recorded at the proper condition. The lowest cutting losses for the tubers mass categories were obtained at $0.08 \mathrm{~m} / \mathrm{s}$ of the plunger speed. Both of the manual and optimum mechanical cutting operations were recorded less than 5\% of the injury. The estimated cost of the potato cutting prototype saved about 50\% from the manual cutting.
\end{abstract}

\section{INTRODUCTION}

$\mathrm{P}$ otato (Solanum tuberosum L.) is ranked as one of the most important vegetable crops in the world; it occupies the second place in acreage and production after seed crops (Anonymous, 2010). In Egypt, the potato crop is one of the major vegetable crops and occupies first place in the export and ranked second in the planting area between the vegetable crops. The cultivated area is about $178 \times 10^{3}$ ha produced around $4800 \times 103 \mathrm{Mg}$ (FAO Statistical Yearbook, 2013).

\footnotetext{
* Researcher, Agric. Eng. Res. Institute, Agric. Res. Center, Dokki, Egypt.

** Head of Researcher, Agric. Eng. Res. Institute, Agric. Res. Center, Dokki, Egypt.
} 
A mechanical potato seed cutting prototype was developed and evaluated in the Faculty of Agricultural Engineering and Technology, University of Agriculture, Faisalabad (Ahmad et al., 1999). They added that, main objectives of the study were to compare the performance of potato seed cutter with manual and to evaluate cutting prototype performance. The mechanical system of potato cutting was found more economical and reducing cutting time compared to manual cutting. The prototype proper speed was $8.75 \mathrm{rpm}$. The prototype output varied from 0.430 to 0.466 $\mathrm{Mgh}^{-1}$. Lipskilet al. (1992) worked on design of an automated unit for potato cutting with productivity of $6 \mathrm{Mgh}^{-1}$. Under this machine tubers conveyed through a cleaner to a sorter unit, where potatoes tuber of $80 \mathrm{~g}$ separated from the larger one (80-140g). After tubers cutting, they treated by effective chemicals prior and they transported to hoppers ready for planting. The unit had an output of $6 \mathrm{Mgh}^{-1}$. The conventional method of cutting potato tubers is to cut it manually into pieces, each pieces at least, including two or three buds in order to multiply pieces and consequently reduce the cost per unit area (Akhtar, 1987). He added that, scarcity of labor has been a problem during the last decade because labor migration to industrialized cities and foreign countries and therefore, the need for mechanized potato cutting is seriously felt.

Johnson (2004) indicated that, hand cutting minimizes the number of blind pieces, but is slow and labor intensive. Size potatoes before cutting, tubers under $45 \mathrm{~g}$ should not be planted. Tubers weighing between $45 \mathrm{~g}$ but less than $90 \mathrm{~g}$ should be planted whole. Tubers with $90-150 \mathrm{~g}$ should be cut into two pieces and tubers with mass of 150 - 210g should be cut into three pieces. Sort out $300 \mathrm{~g}$ for cutting by hand, or, preferably, for sale to other markets. Disinfect all equipment before each tuber cutting session and between seed lots. Calibrate the tuber cutter daily and between lots. Keep the seed cutter knives sharp and straight to prevent ripping the potato surface. Ripping provides an ideal area for disease organisms to attack the tuber (Bohl $\boldsymbol{e t}$ al., 1995 and Johnson, 2004).

Larger tuber pieces are likely to have multiple eyes, resulting in an increased number of stems per tuber. Until the sprouts generate a new root system, they are dependent upon the nutrients and energy stored in the tuber piece. With undersized tuber pieces, establishment of the resulting plants may be 
delayed or unsuccessful. Care in tuber lot selection, handling, and management is essential for optimizing your return on investment. The cost of production and harvesting will be the same regardless of initial tuber quality (Virginia Cooperative Extension, 2009). Since tubers have approximately the same number of eyes, regardless of size, tuber pieces cut from large tubers are more likely to be "blind" (no viable eyes) (Nielson $\boldsymbol{e t}$ al., 1989). This results in missing hills or skips in the field. Too small a tuber piece produces a weak plant. The ideal tuber piece size is $45-60 \mathrm{~g}$ each tuber piece must have at least one good eye (Niemira et al., 2005).

Varieties such as Shepody that have few eyes per tuber are especially prone to these tuber piece conditions. Large tubers also tend to produce seed pieces that are too large. Tuber pieces larger than $90 \mathrm{~g}$ may not readily flow through the planter, causing skips during planting (Bohl et al., 1995).

Virginia Cooperative Extension (2009) found that cutting tubers results in increased respiration during the healing process, thereby increasing physiological aging in much the same way as bruising. Smooth cuts from sharp knives results in lower respiration and more rapid healing than cuts from dull blades. In comparison to other agricultural crops, the seed cost of potato cultivation is much higher. Bangladesh Agricultural Development Corporation (BADC) reported that the cutting cost of potato is liable to $30-40 \%$ of total production cost (Anon, 2005).

From the previous work, it is clear that the manual potato cutting process is very tedious, intensive labors, time consuming work and costly as well, therefore, the main objective of this study is to design, fabricate and evaluate cutting prototype using potato seed properties, and evaluate the various factors affecting of the prototype performance, which, assure high potato pieces quality, losses reduction, economizes time and energy consumption.

\section{MATERIALS AND METHODS}

In the present study a potato cutting prototype was designed, fabricated and tested at Agricultural Engineering Research Institute (AEnRI), Dokki-Giza in 2013. According to the physical and mechanical properties of potato tuber the prototype was designed. Two randomized samples of potato (Sponta \& Diamond) were taken to measure the related properties and also used to evaluate the cutting prototype performance. 


\section{Cutting Prototype Description}

The prototype consists of three essential parts, included potato cutting, power transmission and feeding systems as shown in Figs. 1 and 2.

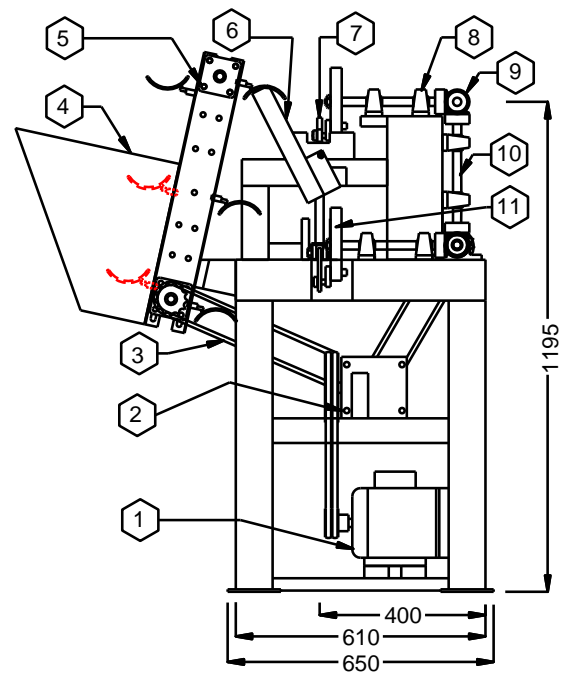

ELEV.

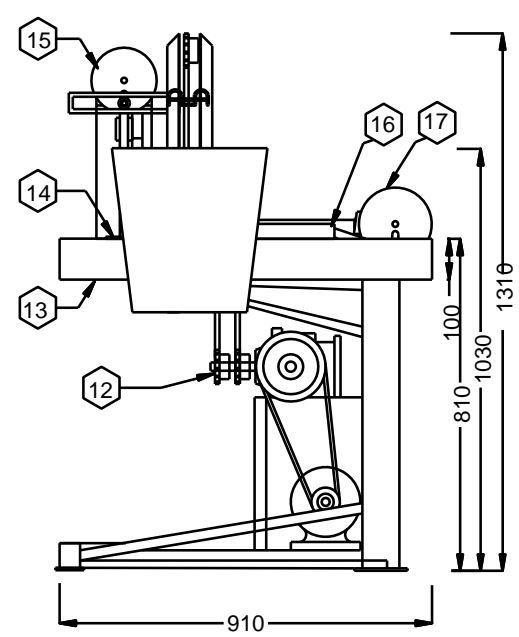

S.D.

13. Frame.

14. A pocket.

15. Crank pulley (B).

16. Connecting rod.

17. Crank pulley (A).

5. A chain-spoon conveyor. 11. Roadblocks.

6. Divider.

12. Sprockets.

7. A plunger.

9. Conical gears

10. Shaft.

Fig. 1: Schematic diagram of potato cutting prototype.

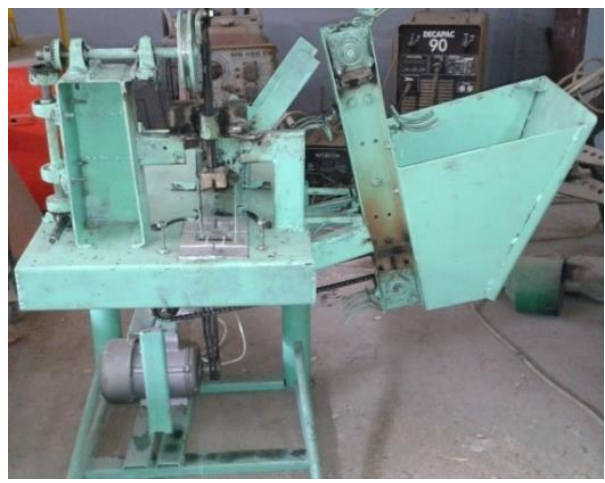

Elevation image.

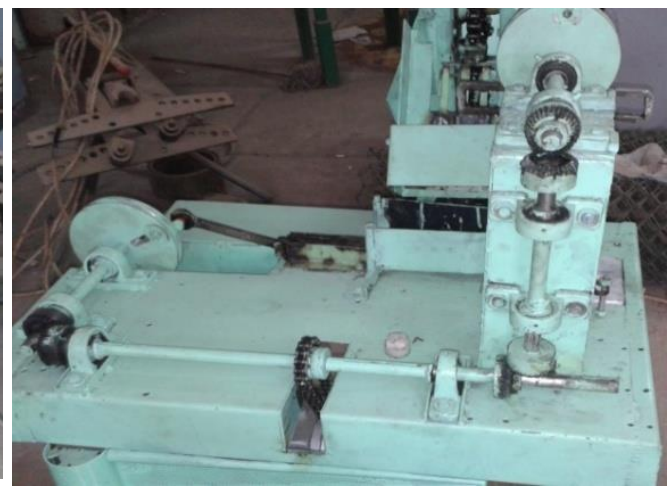

Side image.

Fig. 2: Elevation and side images of potato cutting prototype. 


\section{Potato cutting construction}

The main part of the potato cutting system is a plunger. The upper end of plunger was connecting with a crank pulley (15), to permit a vertical reciprocating motion for plunger.

The plunger lower end is connecting with cutting forming unit to press one tuber above sharp knife. The plunger moves up and down to meet the pocket that, fixed over a frame of $910 \times 650 \times 810 \mathrm{~mm}$ length, width and height respectively. The cut potatoes are discharged through the lower end of the pocket, when the plunger is at the bottom dead center position. Three changeable pockets were designed for each potato variety. The size of each pocket was designed depends on the dimension and the mass category of the potato seed, to cut tuber seed into two or three or four equal pieces. One sharp blade was perpendicularly fixed on the longitudinal of the pocket into the center at the lower end of the pocket to cut tuber seed into two equal pieces. Two parallel sharp blades were perpendicularly fixed on the longitudinal of the pocket with equal distances to cut potato seed into three equal pieces, while to cut the tuber into four equal pieces, two sharp blades at $90^{\circ}$ to each other are fixed in the center of the pocket.

Transmission System: The potato cutting prototype is driven by 0.75 $\mathrm{kW}(1.0 \mathrm{hp})$, single phase electric motor. It is connected with gear box to reduce the speed from 1450 to $29 \mathrm{rpm}$ (50:1) and convert the horizontal rotational motion to vertical. The power of motor was transmitted by gear box using different changeable sizes of pulleys and $\mathrm{V}$-shaped belts, to regulate the cutting speeds $(0.08,0.12$ and $0.16 \mathrm{~m} / \mathrm{s})$.

To prevent the slippage two chains were used to transmit the available power from the gear box sprockets to feeding system and to conical gear.

To receive the motion from gear box and transfer it vertically or horizontally two crank pulleys are established. The first crank pulley (No. 7 in Fig. 3) pushes one tuber into the pocket. There are two flexible roadblocks on both sides of connecting rod for guiding the potato tuber during motion.

The second crank pulley (No. 6 in Fig. 3) transfer motion to the plunger, which results in vertically reciprocating motion of it, up and down to meet one tuber into the pocket to cut it. The motion was adjusted, when 
the plunger at the upper end, the connecting rod of the first crank pulley was forward motion to push one tuber into the pocket and conversely.

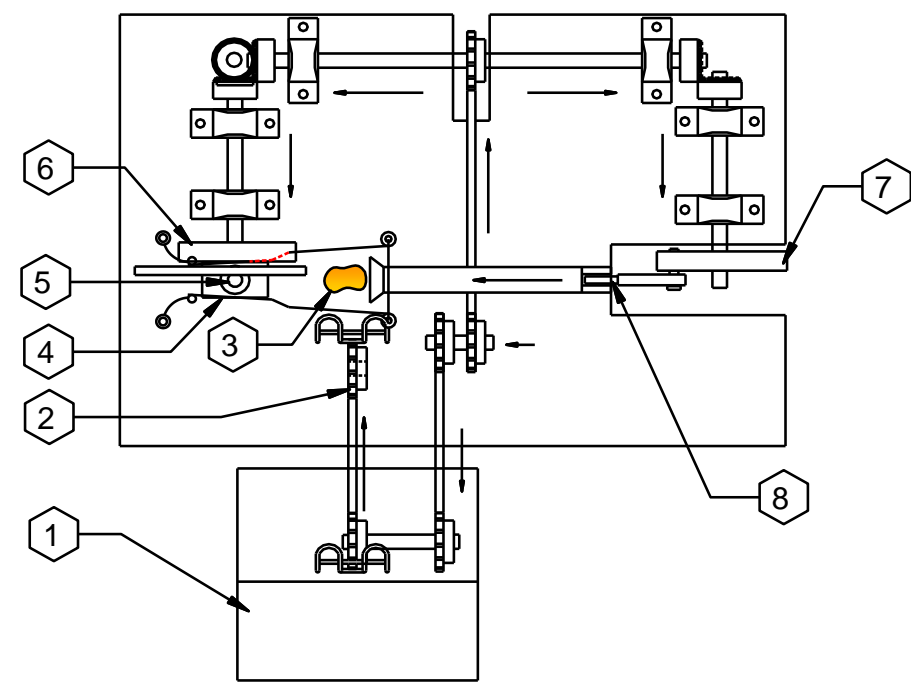
1. Potato seeds hopper.
4. Roadblocks
7. Crank pulley (A).
2. A chain-spoon conveyor.
5. A plunger.
8. Connecting rod.

3. Potato seed.

6. Crank pulley (B).

Fig. 3: Schematic diagram of power transmission system.

Feeding mechanism: The potatoes are mechanically feeding from hopper into the pocket using chain-spoon conveyor. The designed hopper (Fig. 4: A) was constructed from galvanized steel sheets $(2 \mathrm{~mm}$ thickness) a trapezoid cross section shape $(400 \times 380 \times 400 \mathrm{~mm})$. The hopper base has slope angle $40^{\circ}$ on horizontal level in order to keep facilitates the free flow by gravity of the tubers from the hopper to the chain-spoon conveyor. The slope angle was determined according to study of the mechanical properties of the tubers that considered all the affecting factors on the friction and sliding of travelling tubers.

A single tuber is auto-fed to every spoon (six spoons), which lifts upward. Then, the tuber is dropped down on the receiving gate (divider), to guide the falling tuber in the front of the connecting rod of the first crank pulley (No 7 in Fig. 3). Then, the tuber is easily motion into the pocket. 


\section{Physical and mechanical properties of potato tubers.}

The physical and mechanical properties of potatoes tuber were used to design the potato cutting prototype.

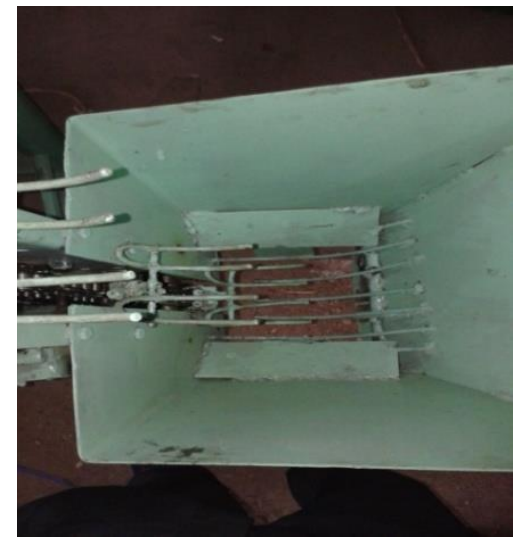

(A) Prototype hopper image.

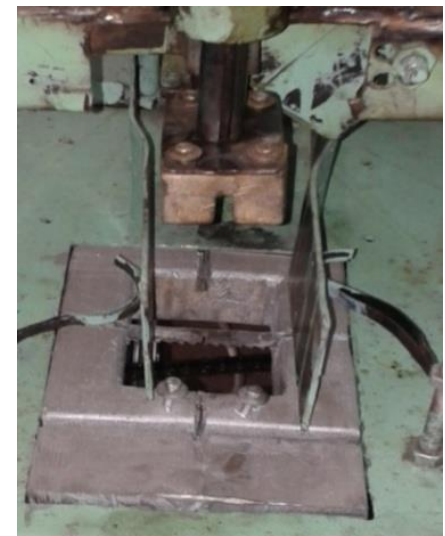

(B) Plunger and pocket image.

Fig. 4: (A) The prototype hopper image, (B) The plunger and pocket image.

Mass, length, width, thickness, shape index, volume and density of two potato tubers (Sponta and Diamond) were measured to identify the mean values (Av.), standard deviation (SD) and coefficient of variation $(\mathrm{CV}, \%)$. Sixty samples were taken randomly and divided into twenty samples for each three mass categories, ranges from 90 - 150, 150 - 210 and $210-300 \mathrm{~g}$.

Tuber mass: It was recorded using digital balance with accuracy of $\pm 0.01 \mathrm{~g}$. A digital caliper with accuracy of $0.01 \mathrm{~mm}$ was used to measure tuber dimension such as [the major axis as tuber length (L-mm), the intermediate diameter as tuber width (D-mm), and the thickness of tuber (T-mm)]. To determine the capacity of prototype hopper, tuber sizes were measured water displaced volume (Mohsenin, 1986). Tuber density is identified as the ratio of tuber mass (M) to its true volume (v).

Shape index of the measured samples was calculated according to (Ismail, 1988) as follows:

$$
I=\frac{L}{\sqrt{D T}}
$$

Where:
I:Shape index
L: Tuber length, mm
D: Tuber width, mm
T: Tuber thickness, mm. 
The obtained data were compared with the recommended limits and classified into two main classes (spherical and oval shapes) to specify the tubers according the calculated shape index for each variety of potato tubers .(I $\leq 1.5$ for spherical while, $\mathrm{I} \geq 1.5$ for oval shape).

The coefficient of friction, repose angle and rolling angle are the main items of the mechanical properties to design the slopes of the hopper and divider of the prototype. The results data of these items were obtained according to (Gamea $\boldsymbol{e t}$ al. 2009). The repose angle was recorded as higher angle than that coefficient of friction and rolling angles. The inclination angle of the hopper and divider must be greater than or equal the repose angle of tuber. The repose angle was found $35^{\circ}$, so the inclination angle of the hopper was designed as $40^{\circ}$.

\section{Tuber cutting prototype performance.}

The target of this experiment was to evaluate the performance of the potato cutting prototype productivity, cutting uniformity, cutting losses, mechanical injury, power and energy requirements were recognized for two potato varieties, three potato mass $(90-150 \mathrm{~g}),(150-210 \mathrm{~g})$ and $(150-210 \mathrm{~g})$ and three plunger speeds $(0.08,0.12$ and $0.16 \mathrm{~m} / \mathrm{s})$.

\section{Cutting prototype productivity}

The productivity of cutting prototype $\left(\mathrm{Mgh}^{-1}\right)$ was defined as follows:

$$
P_{m}=N_{f} \times M_{A v .} \times \frac{60}{10^{-6}}
$$

Where:

$\mathrm{P}_{\mathrm{m}}$ : Cutting prototype productivity, $\mathrm{Mgh}^{-1}$.

$\mathrm{N}_{\mathrm{f}}$ : Number of tubers feeding per min $(=16,24$ and 32 potato tuber/min at $0.08,0.12$ and $0.16 \mathrm{~m} / \mathrm{s}$ of the plunger speed).

$\mathrm{M}_{\mathrm{Av}}$ : Average mass of one tuber for three mass categories, $\mathrm{g}$. $(=134.0,184.8$ and 252.1g for Sponta and 130.6, 181.0 and $245.2 \mathrm{~g}$ for Diamond varieties)

\section{Cutting uniformity}

The uniformity of potato cutting prototype was calculated for each single tuber individually, (Ibrahim and Fasasi, 2004). A sample of twenty tubers was randomly taken for each mass category and varieties were computed as the following equations:

$$
\mathrm{U}_{\text {cutting }}=(1-\mathrm{CV}) \times 100
$$




$$
\begin{gathered}
\mathrm{CV}=\frac{\mathrm{s}}{\overline{\mathrm{X}}} \\
\mathrm{S}=\sqrt{\frac{\sum(\mathrm{X}-\overline{\mathrm{X}})^{2}}{(\mathrm{n}-1)}}
\end{gathered}
$$

Where:

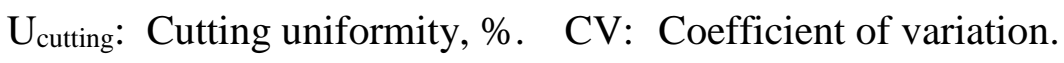

$\mathrm{s}: \quad$ Standard deviation. $\quad \mathrm{X}$ : Mass of a cutting piece, $\mathrm{g}$.

$\overline{\mathrm{X}}$ : Average mass of total cutting tuber.

$\mathrm{n}$ : Number of pieces.

\section{Cutting losses}

The cutting losses include the numbers of blind pieces and the number of mass pieces less than $45 \mathrm{~g}$ and attributed to the total number of each samples. Forty tubers cut by prototype and manual operations for each sample of the previous three categories were taken and calculated according to the following formula:

$$
\mathrm{L}_{\text {cutting }}=\frac{\mathrm{N}_{\mathrm{b}}+\mathrm{N}_{\mathrm{s}}}{\mathrm{N}_{\mathrm{t}}} \times 100
$$

Where:

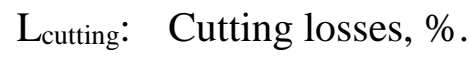

$\mathrm{N}_{\mathrm{b}}$ : Blind pieces number.

$\mathrm{N}_{\mathrm{s}}$ : $\quad$ Pieces mass number, less than $45 \mathrm{~g}$.

$\mathrm{N}_{\mathrm{t}}$ : Pieces total number.

\section{Mechanical injury of cut tubers}

The surfaces injury of cut pieces that results from the prototype and manual operation were separated to observe any damage based on visual inspection (sensory evaluation). According to (Kader, 1992) the mechanical injury in table 1 can be classified into the following categories:

Table 1: Categories of fruits mechanical injury (Kader, 1992)

\begin{tabular}{|c|c|c|}
\hline No. & Injury Categories & No. of fruits injured, $\%$ \\
\hline 1 & No symptoms & 0 \\
\hline 2 & Slight & $<2$ \\
\hline 3 & Moderate & $2-5$ \\
\hline 4 & Severe & $5-10$ \\
\hline 5 & Extreme & $>10$ \\
\hline
\end{tabular}




\section{Power and energy requirements for the cutting prototype}

The power requirement $(\mathrm{kW})$ for potato cutting prototype was estimated from the following equation (Chancellor, 1981) and (Ibrahim, 1982):

$$
\mathrm{P}=(\mathrm{I} \times \mathrm{V} \times \cos \theta) / 1000
$$

Where:

P: $\quad$ Power requirement for cutting potato seed, at different operational parameters, $\mathrm{kW}$.

I: $\quad$ Current strength, Amperes.

V: $\quad$ Potential difference, Voltage.

$\operatorname{Cos} \theta$ : Power factor, equal 0.85 .

The specific energy consumption (SEC) in $\mathrm{kWh} \mathrm{Mg}^{-1}$ was calculated using the following equation:

$$
\mathrm{SEC}=\mathrm{P} / \mathrm{P}_{\mathrm{m}}
$$

\section{RESULTS AND DISCUTION}

\section{Physical properties of potato}

Table 2 shows the mass, length, width, thickness, shape index, volume and density for the two potato varieties (Sponta and Diamond) were measured and determined to get the mean values (Av.), standard deviation (SD) and coefficient of variation $(\mathrm{CV}, \%)$. The potato tuber dimensions were mainly properties to design the pocket sizes which must be equal or greater than the maximum dimensions of the three tuber mass categories for two varieties. The maximum sizes (length and width) for $\mathrm{C}_{\mathrm{m} 1}$ 105.2, $63.1 \mathrm{~mm}$ and 79.2, 67.1 $\mathrm{mm}$ were obtained, 121.2, $69.4 \mathrm{~mm}$ and 89.1, $77.2 \mathrm{~mm}$ for $\mathrm{C}_{\mathrm{m} 2}$, however, for $\mathrm{C}_{\mathrm{m} 3}$ were $155.0,69.1 \mathrm{~mm}$ and 107.7, $87.2 \mathrm{~mm}$ for the Sponta and Diamond respectively.

\section{Prototype productivity}

Figs. 5 and 6 showed prototype productivity increased with increasing the plunger speeds for all treatments under studies. It was increased by $100 \%$ by increasing prototype speed from 0.08 to $0.16 \mathrm{~m} / \mathrm{s}$ at $\mathrm{C}_{\mathrm{m} 1}, \mathrm{C}_{\mathrm{m} 2}$ and $\mathrm{C}_{\mathrm{m} 3}$, also it was increased by $88 \%$ by increasing the tubers mass categories from $\mathrm{C}_{\mathrm{m} 1}$ to $\mathrm{C}_{\mathrm{m} 3}$ at $0.08,0.12$ and $0.16 \mathrm{~m} / \mathrm{s}$ of prototype speed for Sponta and Diamond respectively.

The maximum productivity of 0.484 and $0.471 \mathrm{Mgh}^{-1}$ were obtained at seed tubers mass category $\mathrm{C}_{\mathrm{m} 3}$ and $0.16 \mathrm{~m} / \mathrm{s}$ for two varieties respectively. 
Meanwhile, the minimum productivity of 0.129 and $0.125 \mathrm{Mgh}^{-1}$ were obtained at mass category $\mathrm{C}_{\mathrm{m} 1}$ and $0.08 \mathrm{~m} / \mathrm{s}$ for two varieties, respectively.

Table 2: Physical properties of the potato seed varieties.

\begin{tabular}{|c|c|c|c|c|c|c|c|c|c|c|c|}
\hline \multirow{3}{*}{$\begin{array}{l}\text { Physical } \\
\text { properties }\end{array}$} & \multirow{3}{*}{$\begin{array}{c}\text { Mass } \\
\text { Categories }\end{array}$} & \multicolumn{10}{|c|}{ Potato seed varieties } \\
\hline & & \multicolumn{5}{|c|}{ Sponta } & \multicolumn{5}{|c|}{ Diamond } \\
\hline & & Max. & Min. & Av. & SD & $\mathrm{CV}$ & Max. & Min. & Av. & SD & $\mathrm{CV}$ \\
\hline \multirow{3}{*}{$\begin{array}{c}\text { Mass, } \\
\mathrm{g}\end{array}$} & $\mathrm{C}_{\mathrm{m} 1}$ & 149.6 & 97.5 & 134.0 & 13.7 & 10.2 & 149.6 & 96.2 & 130.6 & 14.9 & 11.4 \\
\hline & $\mathrm{C}_{\mathrm{m} 2}$ & 209.0 & 154.2 & 184.8 & 18.8 & 10.2 & 207.4 & 155.0 & 181.0 & 16.4 & 9.0 \\
\hline & $\mathrm{C}_{\mathrm{m} 3}$ & 299.6 & 205.6 & 252.1 & 28.3 & 11.2 & 299.4 & 218.3 & 245.2 & 23.6 & 9.6 \\
\hline \multirow{3}{*}{$\begin{array}{l}\text { Length, } \\
\mathrm{mm}\end{array}$} & $\mathrm{C}_{\mathrm{m} 1}$ & 105.2 & 69.8 & 88.3 & 9.3 & 10.6 & 79.2 & 58.2 & 70.4 & 5.5 & 7.9 \\
\hline & $\mathrm{C}_{\mathrm{m} 2}$ & 121.2 & 73.6 & 90.0 & 11.1 & 12.3 & 89.1 & 66.2 & 78.1 & 5.9 & 7.6 \\
\hline & $\mathrm{C}_{\mathrm{m} 3}$ & 155.0 & 98.1 & 116.4 & 14.5 & 12.5 & 107.7 & 78.3 & 95.6 & 7.6 & 8.0 \\
\hline \multirow{3}{*}{$\begin{array}{c}\text { Width, } \\
\text { mm }\end{array}$} & $\mathrm{C}_{\mathrm{m} 1}$ & 63.1 & 48.1 & 54.8 & 3.7 & 6.8 & 67.1 & 52.1 & 60.2 & 4.9 & 8.1 \\
\hline & $\mathrm{C}_{\mathrm{m} 2}$ & 69.4 & 48.2 & 62.5 & 4.7 & 7.6 & 77.2 & 62.1 & 68.6 & 4.7 & 6.9 \\
\hline & $\mathrm{C}_{\mathrm{m} 3}$ & 69.1 & 60.2 & 64.9 & 2.6 & 4.0 & 87.2 & 60.6 & 74.6 & 5.7 & 7.7 \\
\hline \multirow{3}{*}{$\begin{array}{c}\text { Thickness, } \\
\text { mm }\end{array}$} & $\mathrm{C}_{\mathrm{m} 1}$ & 52.1 & 38.1 & 44.7 & 4.0 & 9.0 & 59.4 & 48.1 & 51.9 & 3.2 & 6.2 \\
\hline & $\mathrm{C}_{\mathrm{m} 2}$ & 58.1 & 42.3 & 49.8 & 4.1 & 8.3 & 68.4 & 52.4 & 61.4 & 3.8 & 6.2 \\
\hline & $\mathrm{C}_{\mathrm{m} 3}$ & 54.6 & 47.2 & 50.7 & 2.4 & 4.7 & 74.5 & 50.7 & 65.9 & 6.0 & 9.0 \\
\hline \multirow{3}{*}{ Shape index } & $\mathrm{C}_{\mathrm{m} 1}$ & 2.0 & 1.5 & 1.8 & 0.1 & 7.4 & 1.5 & 1.1 & 1.3 & 0.1 & 8.7 \\
\hline & $\mathrm{C}_{\mathrm{m} 2}$ & 2.2 & 1.3 & 1.6 & 0.2 & 12.9 & 1.5 & 1.0 & 1.2 & 0.1 & 8.5 \\
\hline & $\mathrm{C}_{\mathrm{m} 3}$ & 2.8 & 1.8 & 2.0 & 0.2 & 12.1 & 1.6 & 1.1 & 1.4 & 0.1 & 9.1 \\
\hline \multirow{3}{*}{$\begin{array}{l}\text { Volume, } \\
\mathrm{cm}^{3}\end{array}$} & $\mathrm{C}_{\mathrm{m} 1}$ & 140.0 & 95.0 & 124.0 & 11.9 & 9.6 & 140.0 & 85.0 & 118.3 & 17.1 & 14.5 \\
\hline & $\mathrm{C}_{\mathrm{m} 2}$ & 215.0 & 139.7 & 172.5 & 22.5 & 13.0 & 205.0 & 125.0 & 157.5 & 19.8 & 12.6 \\
\hline & $\mathrm{C}_{\mathrm{m} 3}$ & 290.0 & 195.0 & 236.1 & 27.6 & 11.7 & 285.0 & 190.0 & 223.3 & 26.4 & 11.8 \\
\hline \multirow{3}{*}{$\begin{array}{c}\text { Density, } \\
\mathrm{g} / \mathrm{cm}^{3}\end{array}$} & $\mathrm{C}_{\mathrm{m} 1}$ & 1.3 & 1.0 & 1.1 & 0.1 & 6.9 & 1.2 & 1.0 & 1.1 & 0.1 & 8.5 \\
\hline & $\mathrm{C}_{\mathrm{m} 2}$ & 1.3 & 1.0 & 1.1 & 0.1 & 5.9 & 1.3 & 1.0 & 1.2 & 0.1 & 7.5 \\
\hline & $\mathrm{C}_{\mathrm{m} 3}$ & 1.2 & 1.0 & 1.1 & 0.1 & 7.0 & 1.3 & 1.0 & 1.1 & 0.1 & 7.7 \\
\hline
\end{tabular}

$\mathrm{C}_{\mathrm{m} 1}$ : category 1 , mass $(90-150 \mathrm{~g})$.

$\mathrm{C}_{\mathrm{m} 2}$ : category 2 , mass $(150-210 \mathrm{~g})$.

$\mathrm{C}_{\mathrm{m} 3}$ : category 3 , mass $(210-300 \mathrm{~g})$.

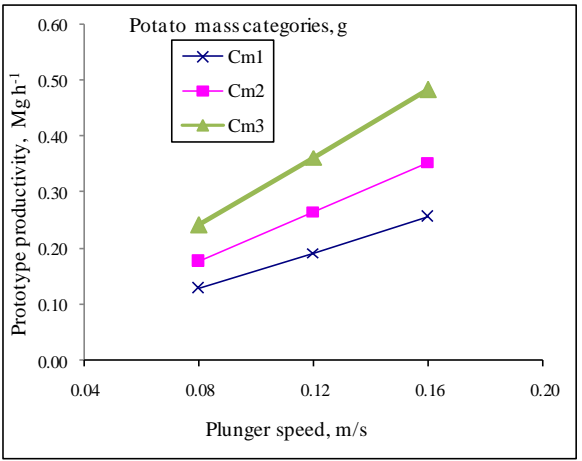

Fig. 5: Effect of different plunger speeds on the prototype productivity $\mathrm{Mgh}^{-1}$ at mass categories of Sponta.

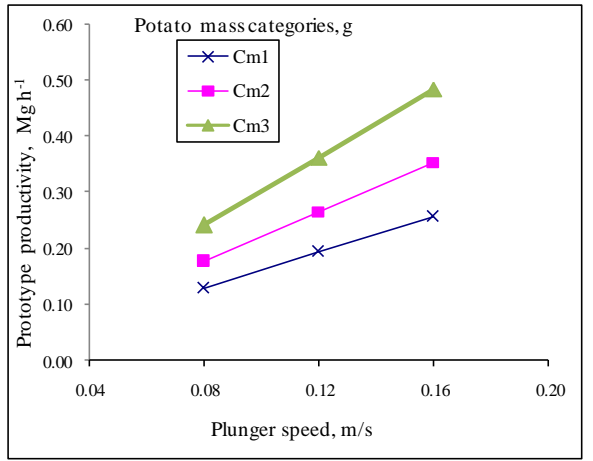

Fig. 6: Effect of different plunger speeds on the prototype productivity $\mathrm{Mgh}^{-1}$ at mass categories of Diamond. 
Multiple regression analysis was carried out to obtain a relationship between the productivity as dependent variables. The best fit for this relationship is presented in the following equation:-

$$
\begin{array}{ll}
\mathrm{SP}_{\mathrm{m}}=-0.170+0.018 \mathrm{~S}+0.085 \mathrm{C}_{\mathrm{m}} & \mathrm{R}^{2}=0.96 \\
\mathrm{DP}_{\mathrm{m}}=-0.165+0.017 \mathrm{~S}+0.082 \mathrm{C}_{\mathrm{m}} & \mathrm{R}^{2}=0.96
\end{array}
$$

Where:

$\mathrm{SP}_{\mathrm{m}}$ : Prototype productivity for Sponta, $\mathrm{Mgh}^{-1}$.

$\mathrm{DP}_{\mathrm{m}}$ : Prototype productivity for Diamond, $\mathrm{Mgh}^{-1}$.

S: $\quad$ Plunger speed, $\mathrm{m} / \mathrm{s}$.

\section{Cutting uniformity}

Figs. 7 and 8 show cutting uniformity as affected by plunger speeds and seed tubers mass categories compared with manual cutting operation for Sponta and Diamond varieties. It indicated that uniformity of cutting increased by increasing the seed tubers mass categories from $\mathrm{C}_{\mathrm{m} 1}$ to $\mathrm{C}_{\mathrm{m} 3}$. While, it decreased by increasing the plunger speeds from 0.08 to $0.16 \mathrm{~m} / \mathrm{s}$ where, it reached the highest values $81.3 \& 76.3 \%$ at $\mathrm{C}_{\mathrm{m} 3}$ and $0.08 \mathrm{~m} / \mathrm{s}$ plunger speed and the lowest values $42.2 \& 28.3 \%$ was obtained at $\mathrm{C}_{\mathrm{m} 1}, \mathrm{C}_{\mathrm{m} 3}$ and $0.16 \mathrm{~m} / \mathrm{s}$ plunger speed for Sponta and Diamond varieties respectively. On the other hand, manual cutting operation decreased with increasing tubers mass categories from 82 to $73 \%$ and from 84.2 to $71.3 \%$ for the two varieties respectively.

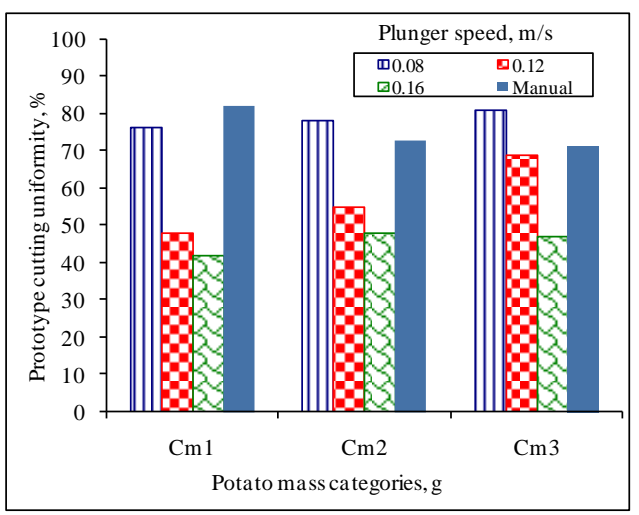

Fig. 7: Effect of different plunger speeds on the prototype cutting uniformity, $\%$ at mass categories of Sponta.

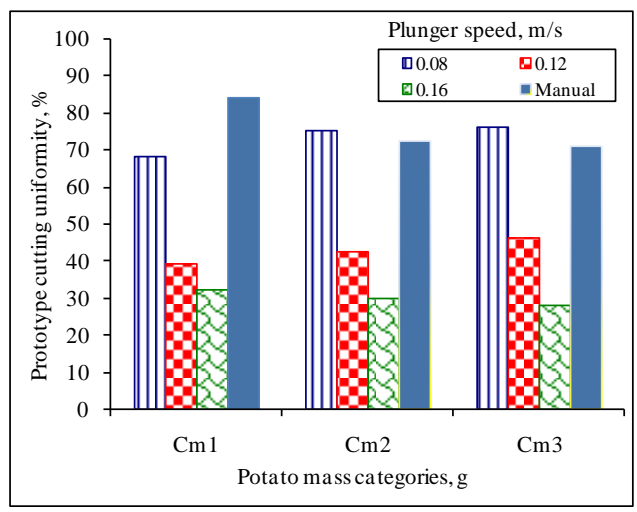

Fig. 8: Effect of different plunger speeds on the prototype cutting uniformity, $\%$ at mass categories of Diamond. 
Generally, the Sponta recorded the higher uniformity of cutting than that Diamond. The optimum uniformity of the cutting prototype was obtained at $0.08 \mathrm{~m} / \mathrm{s}$ of plunger speed for all potato mass categories. Comparative performance of the mechanically cutting technique at $0.08 \mathrm{~m} / \mathrm{s}$ of the plunger speed gave similar or more cutting uniformity than traditional technique. These results are accordance with (Ahmad et al., 1999).

The total interaction between different variables of the plunger speeds and potato seed mass categories shows a significant effect with $(\mathrm{R} 2=0.91 \&$ 0.93 for Sponta and Diamond). The obtained regression equations were in the form of:

$$
\begin{aligned}
\mathrm{SU}=101.63-3.35 \mathrm{~S}+4.83 \mathrm{C}_{\mathrm{m}} & \mathrm{R}^{2}=0.91 \\
\mathrm{DU}=109.77-4.31 \mathrm{~S}+1.83 \mathrm{C}_{\mathrm{m}} & \mathrm{R}^{2}=0.93
\end{aligned}
$$

Where:

SU: Cutting uniformity for Sponta.

DU: Cutting uniformity for Diamond.

\section{Cutting losses}

Figs. 9 and 10 indicated that cutting losses increased with increasing the potato mass categories from $\mathrm{C}_{\mathrm{m} 1}$ to $\mathrm{C}_{\mathrm{m} 3}$ and the different plunger speeds from 0.08 to $0.16 \mathrm{~m} / \mathrm{s}$ for two varieties. This may be due to the effect of the number of buds per each tuber (Bohl et al., 1995).

The lowest cutting losses for the tubers mass categories were obtained at $0.08 \mathrm{~m} / \mathrm{s}$ plunger speed. Both of the mechanical and manual cutting gave the equal effect for the cutting losses.

The best fit regression was obtained as follows:-

$$
\begin{aligned}
& \mathrm{SL}=-21.52+2.25 \mathrm{~S}+5.41 \mathrm{C}_{\mathrm{m}} \quad \mathrm{R}^{2}=0.98 \\
& \mathrm{DL}=-17.50+2.17 \mathrm{~S}+6.25 \mathrm{C}_{\mathrm{m}} \quad \mathrm{R}^{2}=0.96
\end{aligned}
$$

Where:

SL: Cutting losses for Sponta.

DL: Cutting losses for Diamond.

\section{Mechanical injury of potato cutting}

Table 3 shows mechanical injury as affected plunger speed and potato mass category for two potato varieties. The injury of the manual cutting also considered. 
The lowest value of injury (moderate) was obtained for two previous varieties at $0.08 \mathrm{~m} / \mathrm{s}$ of plunger speed and all potato mass categories, except for one sever case at $\mathrm{C}_{\mathrm{m} 3}$ of Diamond. Generally, both of the manual and optimum mechanical cutting operations were recorded less than $5 \%$ of the injury.

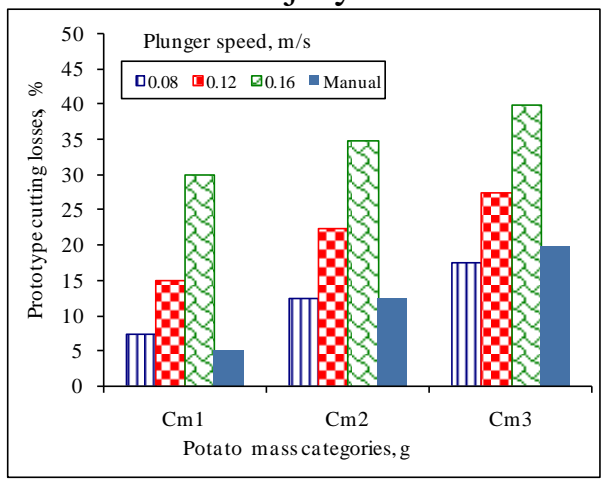

Fig. 9: Effect of different plunger speeds on the prototype cutting losses, $\%$ at mass categories of Sponta.

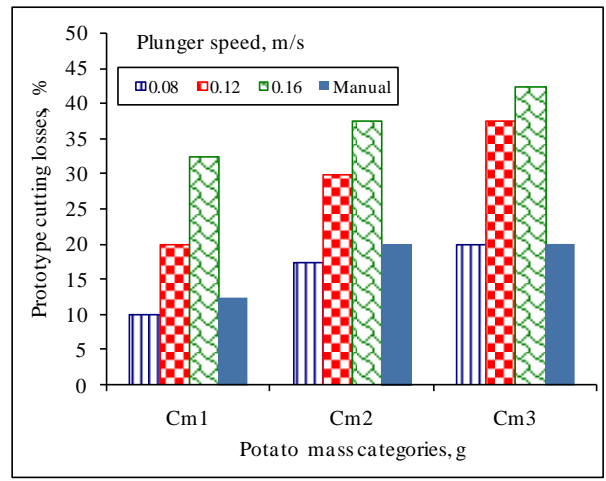

Fig. 10: Effect of different plunger speeds on the prototype cutting losses, $\%$ at mass categories of Diamond.

Table 3: Mechanical injury of potato cutting

\begin{tabular}{|c|c|c|c|c|c|c|}
\hline \multirow{2}{*}{$\begin{array}{c}\text { Plunger } \\
\text { speeds, } \\
\mathrm{m} / \mathrm{s}\end{array}$} & \multicolumn{5}{|c|}{ Potato seed varieties } \\
\cline { 2 - 7 } & \multicolumn{4}{|c|}{ Sponta } & \multicolumn{3}{c|}{ Diamond } \\
\cline { 2 - 7 } & Potato seed mass categories & \multicolumn{2}{|c|}{ Potato seed mass categories } \\
\hline 0.08 & $\mathrm{C}_{\mathrm{m} 1}$ & $\mathrm{C}_{\mathrm{m} 2}$ & $\mathrm{C}_{\mathrm{m} 3}$ & $\mathrm{C}_{\mathrm{m} 1}$ & $\mathrm{C}_{\mathrm{m} 2}$ & $\mathrm{C}_{\mathrm{m} 3}$ \\
\hline 0.12 & Severate & Moderate & Moderate & Moderate & Moderate & Severe \\
\hline 0.16 & Extreme & Extreme & Extreme & Extreme & Extreme & Extreme \\
\hline $\begin{array}{c}\text { Manual } \\
\text { potato } \\
\text { seed cutting }\end{array}$ & $\begin{array}{c}\text { No } \\
\text { symptoms }\end{array}$ & $\begin{array}{c}\text { No } \\
\text { symptoms }\end{array}$ & Moderate & $\begin{array}{c}\text { No } \\
\text { symptoms }\end{array}$ & Extreme & Extreme \\
\hline
\end{tabular}

\section{Specific energy consumption (SEC)}

Results illustrated in Figs. 11 and 12, show that the specific energy consumption decreased with increasing both the plunger speeds and potato mass categories. The highest consumed of specific energy (3.34 and $3.73 \mathrm{kWhMg}^{-1}$ ) were recorded at $0.08 \mathrm{~m} / \mathrm{s}$ plunger speed and $\mathrm{C}_{\mathrm{m} 1}$, while the lowest consumed specific energy $\left(1.28\right.$ and $\left.1.31 \mathrm{kWhMg}^{-1}\right)$ 
were recorded at $0.16 \mathrm{~m} / \mathrm{s}$ plunger speed and $\mathrm{C}_{\mathrm{m} 3}$ for Sponta and Diamond respectively.

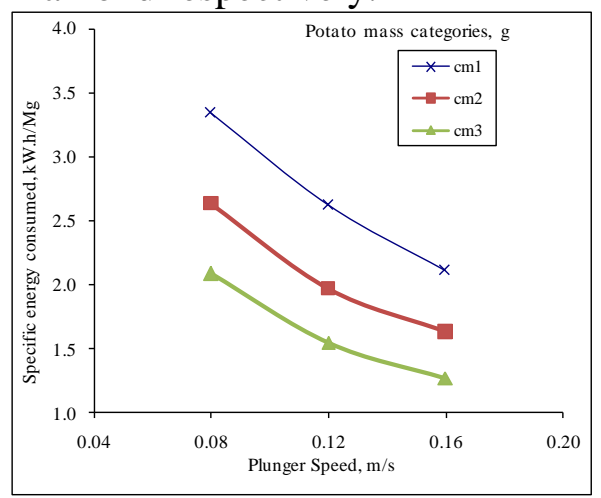

Fig. 11: Effect of different plunger speeds on the specific energy consumption, $\quad \mathrm{kWhMg}^{-1}$ at mass categories of Sponta.

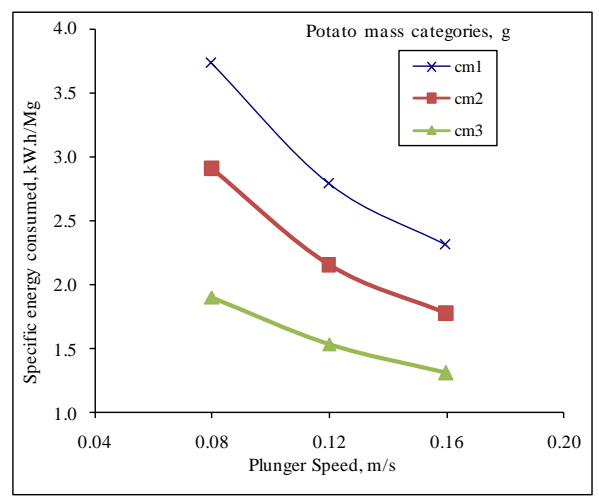

Fig. 12: Effect of different plunger speeds on the specific energy consumption, $\mathrm{kWhMg}^{-1}$ at mass categories of Diamond

\section{Cutting operation costs}

The total hourly cost was $16.95 \mathrm{EGP} / \mathrm{h}$, and the average cutting cost per one $\mathrm{Mg}$ potato of $92.65 \mathrm{EGP} / \mathrm{Mg}$, was obtained at the proper conditions, in comparison with $200 \mathrm{EGP} / \mathrm{Mg}$ for the manual cutting (or in other words it was about 2 times higher than that of the mechanical cutting).

\section{SUMMARY AND CONCLUSION}

A prototype of cutting potato was designed, fabricated, and evaluated under two potato varieties, three plunger speeds and three mass categories. From the obtained results it can be recommended that the potato cutting prototype used at $0.08 \mathrm{~m} / \mathrm{s}$ plunger speed for three potato seed categories to increase the prototype cutting uniformity (76.8, 78.4 and 81.3 for Sponta and 68.2, 78.4 and 81.3 for Diamond) and reduce the losses and the mechanical injury (less than 5\%).

\section{ACKNOWLEDGEMENT}

The authors gratefully acknowledge the help and support of Eng. Ahmed El-Attar, Dr. Khalil sayed Khalil and Dr. Mohamed Abdel Gelil of Agric. Eng. Res. Inst (AEnRI), Dokki, Egypt. 


\section{REFERENCES}

Ahmad, M.; M. Younis and I. Saeed (1999). Performance Evaluation of a Mechanical Potato Seed Cutting Prototype. Pakistan Journal of Biological Sciences, 2 (4): 1527-1532.

Akhtar, M. (1987). Vegetables of Punjab. Dept. of Agriculture, Govt. of the Punjab, Lahore.

Anon (2005). Cultivation registers of Domar Foundation Seed Potato Production Farm for 2004-05 production years, Bangladesh Agricultural Development Corporation (BADC), Domar, Nilphamari.

Anonymous (2010). Annual Report, 2009-10. Tuber Crops Research Centre, BARI, Joydebpur, Gazipur 1701. 202 p.

Bohl, W. H., P. Nolte, G. E. Kleinkopf and M. K. Thornton (1995). Potato seed management: seed size and age. Univ. of ID Coop. Ext. Sys. CIS1031. http:// info.ag. uidaho. edu/ Resources/ PDFs/CIS1031.pdf (2/16/05)

Central Administration of Agricultural Extension and the environment (2014). cultivation and production of potatoes. Agricultural Research Center. Bulletin No.1304: 12 P. (In Arabic)

Chancellor, W. J. (1981). Substituting information for energy in agricultural. Trans. ASAE, Paper No. 0001-2351.

FAO Statistical Yearbook (2013). Area harvested and production of starchy roots and tubers.

Gamea, G. R.; M. A. Abd El-Maksoud and A. M. Abd El-Gawad (2009). Physical characteristics and chemical properties of potato tuber under different storage systems. Misr J. Ag. Eng., 26(1): 385408

Ibrahim, M. K. E. (1982). Wet milling Wheat Grain.Master thesis of science.Fac.Of Agric. Mansoura Univ., 64-65. 
Ibrahim, S. O. and M. B. Fasasi (2004). Design and development of a portable feed mixer for small-scale poultry farmers. Proc. NIAE 26, Nov. 28- Dec. 2, Ilorin.

Ismail, Z. E. (1988). Some of the physio- mechanical properties for potato planters. J. Agric. Sci. Mansoura Uni., 13 (4), 2259 - 2270.

Johnson, S. B. (2004). Selecting, cutting and handling potato seed.

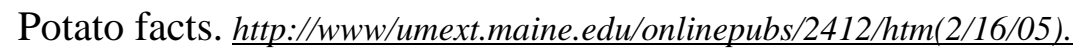

Kader, A. A. (1992). Postharvest Technology of Horticultural Crops.Pub.3311 California Univ. Division of Agric. and Natural Res. 600 p.

Lipskil, N. Y. ; N. N. Lokhach ; A. S. Moisa and A. R. Kolinj (1992). An Automated Unit for potato seed cutting. Dept. of Agril.Eng. Shafi, A, 1990. Design and development of a potato seed cutter. M.Sc. Thesis, Univ. of Agri. Faisalabad. Abstract, 7: 15-19.

Mohsenin, N.N. (1986). Physical properties of plant and animal materials.Gordon of Breach science publishers, New York.

Nielson, M.; W. M. Iritani and L. D. Weller (1989). Potato Seed Productivity: Factors influencing eye number per seed piece and subsequent performance. American Potato J. 151-160.

Niemira, B. A.; W. W. Kirk; R. Schafer; J. M. Stein and R. S. Shaw (2005). Effect of whole seed piece weight, planting density, and a soil stimulant on yield in commercial seed potato and chip potato fields.

Virginia Cooperative Extension (2009). Potato seed selection and management. S. B. Sterrett VA Tech, and Eastern Shore Agricultural Research. Virginia Polytechnic Institute and State University, Virginia Cooperative Extension programs and employment.www.ext.vt.edu. 


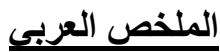

\section{تطوير نموذج أولى لتجزئة تقاوي درنات البطاطس}

د. حسام محمد طلبة الغباشي*, أ.د. إبراهيم يحي السيد**, د. يسرى عبد القوى شعبان* نظر الكرتفاع العالمي المستمر في أسعار تقاوي البطاطس والتي غالباً ما يتم استير ادها وللاستفادة من انخفاض أسعار التقاوي المستوردة ذات الأحجام الكبيرة مقارنة بأسعار التقاوي

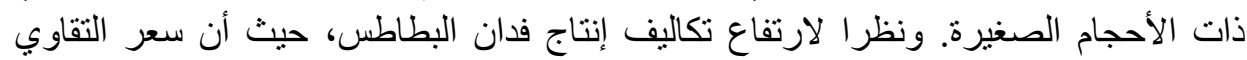
وحدة يمثل حوالي من 0_. ٪\% من جملة التكاليف وللعمل على خفض تلك التكاليف بقدر المستطاع يمكن زر اعة البطاطس في مصر بتقاوي مجز اة مع مر اعاة بعض الاحتياطات الفنية

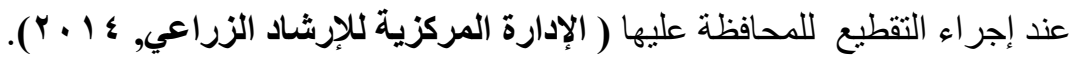

لذا كان الهدف من هذا البحث تصميم وتصنيع وتقييم نموذج أولى لتجزئة تقاوي درنات البطاطس محلي الصنع. تم تصميم وتصنيع هذا النموذج بناءا على الخواص اصل الطبيعية

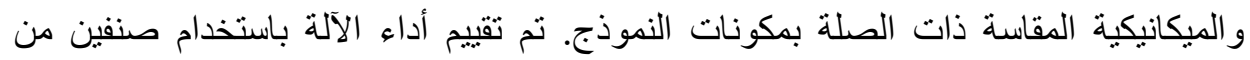
البطاطس إحداهما بيضاوي (أسبونتا) و الأخر مستدير (دياموند) مع استخدام ثنلاثة فئات لكتلة

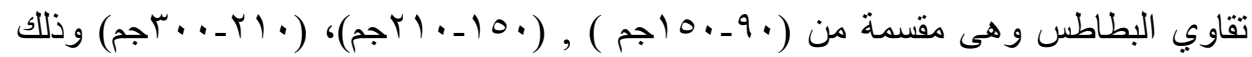
لتقطيع الدرنة إما إلى جزئيين أو ثثلاثة أو أربعة أجزاء هلى هلى التوالي مع ثناثنة سرعات خطية

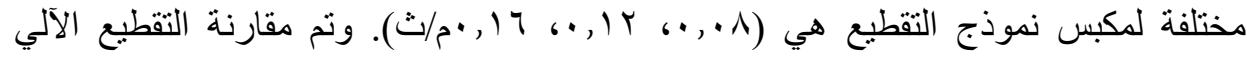
بالتقطيع اليدوي.

وكانت أهم النتائج المتحصل عليها أنه يمكن استخدام النموذج الأولى تحت الدراسة عند سرعة أله

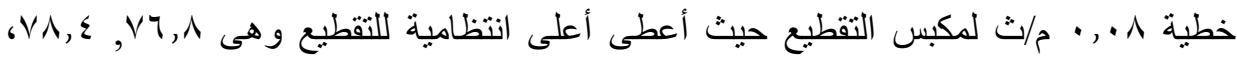

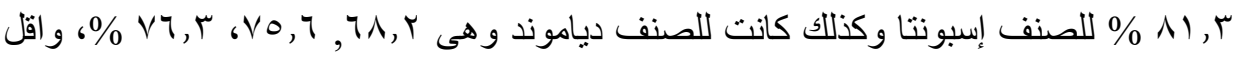
نسبة للفقد ونسبة أضرار ميكانيكية وذللك عند كل فئات تدريج تقاوي البطاطس تحت الدراسة. ويعتبر النموذج الأولى المقترح اقتصادياً حيث يوفر حوالي .0 \% و أو أكثر من التكاليف مقارنة بالتقطيع اليدوي.

\footnotetext{
* باحث - معهل بحوث الهندسة الزراعية ـ مركز البحوث الزراعية ـ دقى - جيزة. * * رئيس بحوث - معهل بحوث الهندسة الزراعية ـ مركز البحوث الزراعية ـ دقى - جيزة.
} 